\title{
PERLINDUNGAN HUKUM BAGI KONSUMEN PADA BANK BEKU OPERASI
}

\author{
A. A. N. Bagus Krisna Pratama, Ni Luh Made Mahendrawati, Ni Made Puspasutari Ujianti \\ Fakultas Ilmu Hukum Universitas Warmadewa, Denpasar - Bali, Indonesia \\ gungkrisna731@yahoo.co.id, made.mahendrawati@gmail.com, puspa.niwapong@gmail.com
}

\begin{abstract}
Abstrak
Pertumbuhan rakyat yang sangat cepat dan pertumbuhan ekonomi yang ini tidak stabil menyebabkan sulitnya seorang mempunyai sebuah tempat tinggal. Rumah pada suatu daerah dijual secara tunai dan kredit. Membeli perumahan mampu dilakukan cara kredit dalam Perbankan. Dalam perjalanannya, bank dipilih yang mengalami kebangkrutan menyebabkan Bank Beku Operasi sebagai akibatnya nasabah dirugikan. Penelitian ini bertujuan untuk mengetahui bagaimana hak dan kewajiban para pihak dalam jual beli perumahan secara kredit pada bank yang dinyatakan beku operasi dan bagaimana upaya penyelesaian jika bank dinyatakan sebagai bank beku operasi bagi nasabah dalam jual beli perumahan secara kredit. Metode yang dipakai pada penulisan ini adalah penelitian hukum normatif, yaitu menelaah permasalahan memakai dasar aturan berupa peraturan perundangundangan. Hasil penelitian ini menunjukan bahwa hak dan kewajiban para pihak dalam jual beli perumahan secara kredit pada bank yang dinyatakan beku operasi dilindungi oleh LPS (lembaga penjamin simpanan). Hak dari konsumen nasabah jika bank mengalami bank beku operasi yaitu mendapatkan perlindungan dari LPS akan menjamin simpanan nasabah baik itu deposito, sertifikat tanah yang menjadi jaminan pada bank, yang pantas membayar dan untuk simpanan tidak pantas membayar atau dijamin pembayarannya dalam mekanisme ketentuan bank dalam beku operasi. Sedangkan kewajiban dari pihak bank kepada nasabah yaitu salah satunya dengan membayar setengah simpanan dari nasabah. Selain itu, upaya penyelesaian apabila bank dinyatakan sebagai bank beku operasi bagi nasabah pada jual beli perumahan secara kredit yaitu dengan cara pemberesan harta bank yang bermasalah dengan mengajukan kepailitan.
\end{abstract}

Kata Kunci: Bank Beku Operasi, Kredit, Perumahan

\begin{abstract}
The very fast growth of the people and the unstable economic growth made it difficult for a person to have a place to live. Houses in an area can be sold by cash and credit. Housing purchases can be done by means of credit in banking. On the way, the selected bank which experienced bankruptcy caused the Bank to Freeze Operations as a result of which the customer was disadvantaged. This study aims to determine how the rights and obligations of the parties in the sale and purchase of housing with credit at the bank which are stated in the frozen operation and how the settlement efforts are if the bank is declared a bank with frozen operations for customers in the sale and purchase of housing loans. The method used in this is normative legal research, which examines the problem using the basic rules in the form of regulations. These results indicate that the rights and obligations of the parties in the sale and purchase of credit housing at a bank that is found guilty are protected by the LPS (deposit insurance agency). The rights of the customer if the bank experiences a bank that has been frozen for operation, which has received protection from the LPS, will guarantee customer deposits, whether it is a time deposit, land certificates that are collateral to the bank, which are eligible to pay and for deposits that are not worth paying or guaranteed payment in the provisions of the bank in frozen operation. Meanwhile, the obligations of the bank to the customer are half the savings from the customer. In addition, efforts to resolve the bank case are declared to be a bank whose customer operations are frozen on credit, namely by way of settling troubled bank assets by filing for bankruptcy.
\end{abstract}

Keywords: Operation Frozen Bank, Credit, Housing

\section{PENDAHULUAN}

Pertumbuhan rakyat yang sangat cepat dan juga pertumbuhan ekonomi yang tidak begitu stabil terdampak dalam susahnya seorang untuk mempunyai sebuah tempat tinggal. Rumah adalah yang mempunyai fungsi sebagai tempat tinggal dan sarana pembinaan suatu keluarga. Masalah pada masyarakat mendapat jawaban yang baik menurut para pengembang properti itu sendiri yang bergerak pada bidang perumahan tadi. Para pengembang properti tempat tinggal menyediakan suatu tempat tinggal menggunakan size dan berbagai banyak tipe supaya bisa terpenuhinya keinginan pembeli 
sesuai dengan kondisi keuangan yang dimiliki seorang yang ingin membeli sebuah tempat tinggal. Rumah yang dibangun oleh pengembang properti pada suatu tempat tertentu dijual pengusaha menggunakan cara tunai dan kredit. Di kehidupan saat ini kredit bukan perkataan yang asing bagi kita. Kata kredit juga dikenal pada kota-kota metropolitan tergolong besar, akan tetapi hingga di desa-desa pun istilah kredit itu telah sangat terkenal. Kredit adalah penyediaan uang yg didasarkan persetujuan di antara bank menggunakan pihak lainnya. Pihak yang meminjam kredit diwajibkan melunasi utangutangnya yang dipinjam sesudah jangka ketika yang ditetapkan dengan diberikan suku bunga yang sudah disetujui pada awal pemberian kredit (Oktafiani \& Idris, 2015).

Manusia adalah homo economicus atau makhluk sosial, dan makhluk sosial akan sering mengusahakan supaya terpenuhinya kebutuhannya. Kebutuhan suatu makhluk hidup yang dimaksud cenderung meningkat, sedangkan upaya tercapainya sesuatu yang diinginkannya itu terbatas. Dengan demikian, itu menjadi penyebab manusia perlu bantuan buat memenuhi keinginan mempunyai tempat tinggal. Pembelian rumah mampu dilakukan dengan cara kredit dalam sektor Perbankan melalui Bank Umum Nasional juga Bank lain yang sejenis.

Bank memiliki peranan strategis dan yang terpenting pada perekonomian suatu bangsa dikarenakan perbankan adalah suatu lembaga yang mampu menghimpun dan menurunkan dana pada warga secara nyata dan juga berdaya guna. Bank juga berasaskan demokrasi ekonomi buat dukungan pada pembangunan merata nasional pada bentuk bisa meningkatkan pertumbuhan ekonomi, kesetaraan pembangunan merata dan stabilitas nasional ke arah peningkatan tingkat hidup rakyat itu sendiri. Oleh karena itu, bank mempunyai kiprah yang luar biasa tidak hanya bisa membangkitkan laju perniagaan nasional, akan tetapi juga dituju agar bisa mewujudkan pembangunan nasional itu sendiri. Bank harus cakap mengatur peranan selaku penyalur dana pembangunan untuk tercapainya tujuan nasional, sehingga tidak ada ganjalan dan hambatan pada dilaksanakannya pembangunan nasional itu sendiri (Hermansyah, 2008).

Kredit juga bisa meningkatkan efektifitas dan peredaran barang. Melalui kredit, penduduk yang hendak ingin memiliki tempat tinggal bisa melakukan jual beli melalui kredit. Membeli properti tempat tinggal melalui kredit adalah membeli suatu barang menggunakan cara pembayaran yang bisa diangsur setiap bulan juga setiap tahun. Para Pihak pada jual Perumahan melalui kredit akan menerima perlindungan aturan apabila pihak-pihak yang bersangkutan sudah memegang suatu bukti tertulis di dalam ikatan perjanjian yang dianggap perjanjian jual beli perumahan secara kredit (Prawira \& Purwanto, 2020).

Perjanjian adalah perbuatan dimana satu orang/ lebih mengikatkan dirinya dalam satu orang lain atau lebih lainnya. Perjanjian itu adalah menerima persetujuan yang bisa dirumuskan melalui cara tertulis dan bisa menerima bukti adanya hak dan kewajiban (Kusumohamidjojo, 1998).

Proses Jual beli adalah suatu kesepakatan di antara satu pihak dengan lain pihak. Satu pihak memberikan hak milik suatu barang, satu pihak lain berjanji buat bayar menggunakan harga yang meliputi sejumlah uang selaku imbalan dalam hasil hak milik tersebut (Subekti, 1995). Seorang atau suatu forum memberikan kredit berkeyakinan maka penerimaan kredit dalam ketika mendatang akan bisa mengklaim seluruh sesuatu yang pernah dijanjikan itu bisa berupa barang, uang, atau jasa.

Bank dalam pemberian kredit pada konsumen, pelunasan kewajiban hutang untuk pembelian tempat tinggal dilandaskan dalam dasarnya saling percaya dan berkeyakinan bahwa konsumen yang mengambil kredit berupaya dan akan mengembalikan kreditnya yang telah diterimanya (Sutianingsih, 2010). Adanya 2 faktor menurut faktor kemauan dan kemampuan itu seyogianya menerima suatu simpulan yaitu unsur keamanan dan unsur laba terdapat dalam suatu kredit. Kedua unsur itu saling berkaitan satu sama lainnya. Keamanan atau paling aman yang dimaksud disini yaitu perolehan yang dihasilkan berbentuk uang, barang, atau suatu jasa yang benar-benar terjamin pengembaliannya, sebagai akibatnya laba yang ditunggu menjadi suatu hal yang nyata. Keuntungan memiliki suatu capaian menurut pengembalian kredit yang diterima berbentuk bunga (Thomas, Chalik, Made, Yunianti, \& Marala, 1999).

Proses jual beli perumahan secara kredit terdapat tiga pihak terkait, yaitu kreditur, debitur, dan suatu pihak lain yang dianggap pihak ketiga. Kreditur memiliki kedudukan hanya pemberi kredit, mampu dikatakan orang yang berpiutang, sementara itu debitur adalah orang yang memperoleh kredit berupa uang. Demikian pihak ketiga adalah orang sebagai penanggung jawab suatu kredit utang debitur bagi kreditur. Pengusaha properti tempat tinggal menjaminkan agunan berupa sertifikat tempat tinggal pada bank yang bertujuan sebagai jaminan dilakukannya hadiah kredit yang diberikan pihak 
bank buat nasabah. Bank adalah suatu badan dan juga tugas utamanya menghimpun uang menurut pihak ketiga yang dimaksud pihak ketiga disini yaitu nasabah (Thomas et al., 2007). Dalam perjalanan bank dipilih mengalami kebangkrutan, kepailitan karena pada korupsi oleh anggota bank menyebabkan bank tersebut mengalami BBO (Bank Beku Operasi) sebagai akibatnya menyebabkan nasabah dirugikan, sebagai upaya untuk menanggulangi masalah tersebut maka akan diuraikan suatu contoh masalah tentang bank yang telah mengalami kepailitan BBO (bank beku operasi) dampak dikorupsi oleh anggota bank dan dampak bagi konsumen nasabah.

Contoh Kasus, Bank Bali mengalami kebangkrutan Kepailitan atau BBO (bank beku operasi). Bank Bali adalah salah satu bank yang pernah terdapat di Indonesia kisaran tahun 1999. Kasus pencucian uang dalam Bank Bali terjadi dalam kurun ketika 1999 itu. Setelah terpidana korupsi masalah dialihkannya hak tagih dalam waktu itu pada bank Bali. Masalah bank Bali dimulai dalam Dirut Bank Bali yaitu Rudy Ramli kesulitan menagih piutangnya dalam brankas Bank Tiara pada tahun 1997 silam, Bank Bank Dagang Nasional Indonesia, Sementara itu Rudy Ramli menciptakan kesepakatan suatu perjanjian dalam PT Era Giat Prima yang mana Djoko Tjandra menjabat direktur, Setya Novanto saat itu sebagai Bendahara Partai Golkar jabat dirut. Pada januari 1999, antara Rudy Ramli dan PT Egp bersepakat dalam kontrak dalam pengalihan hak tagih. PT Egp akan menerima persenan yang banyaknya setengah dari yang bisa ditagih. Dari Perbuatannya PT EGP Djoko Tjandra dan yang bersangkutan dia dituduh menjalankan korupsi yang merugikan banyak pihak termasuk negara. Dari contoh kasus tadi terlihat Bank Bali waktu itu likuidasi dampak pada korupsi sejumlah anggota bank menyebabkan konsumen mengalami kerugian sebagai penyimpan dana pada Bank Bali dan pelaku nasabah kredit tidak terkecuali kredit perumahan mengalami kesulitan membayar kreditannya.

Berdasarkan pemaparan latar belakang di atas, penelitian ini dilakukan dengan tujuan mengungkap apa hak dan kewajiban para pihak dalam jual beli perumahan secara kredit pada bank yang dinyatakan beku operasi dan apa upaya penyelesaian jika bank dinyatakan sebagai bank beku operasi bagi nasabah dalam jual beli perumahan secara kredit.

\section{METODE PENELITIAN}

Metode penelitian yang digunakan dalam penelitian ini adalah penelitian hukum normatif yang mempergunakan menelaah permasalahan menggunakan dasar hukum yang berlaku berupa peraturan perundang-undangan dan ditunjang oleh konsep-konsep pendapat sarjana/doktrin yang masih ada dalam literatur. Penelitian ini juga menggunakan pendekatan suatu konsep dan pendekatan perundangundangan, yaitu pendekatan menggunakan menelaah dari peraturan perundang-undangan dalam hukum positif pada Indonesia dan dari konsep-konsep menurut pendapat para sarjana berkaitan menggunakan permasalahan yang dibahas.

Adapun beberapa sumber bahan aturan baik utama dan sekunder yang dipakai yaitu misalnya Undang-Undang Nomor 4 Tahun 1992 Tentang Perumahan dan Permukiman, Undang-Undang Nomor 8 Tahun 1998 Tentang Perlindungan Konsumen, Undang-Undang Nomor 7 Tahun 1992 Tentang Perbankan Sebagaimana sudah diubah menggunakan Undang-Undang Nomor 10 Tahun 1998, Undang-Undang Nomor 37 Tahun 2004 Tentang Kepailitan. Selain itu juga berpedoman dalam artikel, literatur-literatur, jurnal hukum dan yang lain terkait menggunakan permasalahan. Metode pengumpulan data yang digunakan adalah metode dokumentasi, untuk analisis data metode deskriptif digunakan, dan hasil analisis data disajikan menggunakan metode informal.

\section{HASIL PENELITIAN DAN PEMBAHASAN}

\section{Hak dan Kewajiban Para Pihak dalam Jual Beli Perumahan secara Kredit pada Bank yang} Dinyatakan Beku Operasi

Bank adalah suatu forum yang ada di Indonesia yang merupakan forum perantara bagi pihak atas likuidasi yang dimiliki berlebih dalam dunia usaha, forum pemerintah maupun tempat tinggal menggunakan pihak lainnya yang adalah likuiditasnya kurang.

Dalam membeli tempat tinggal, cara kredit melalui bank umum nasional atau bank sejenisnya bisa digunakan. Hal ini dilakukan dengan menyerahkan agunan sertifikat rumah menjadi jaminan. Pada perjalanannya bank dipilih yang mengalami BBO (bank beku operasi) menyebabkan nasabah dirugikan. Dalam rangka menaruh proteksi aturan bagi konsumen nasabah bank, menurut asas-asas aturan yang terdapat pada aturan perdata dan juga hukum publik setiap orang harus memiliki jaminan, 
perlindungan, dan adanya kepastian hukum, tentu adil dan mendapat perlakuan yang sama di depan aturan.

Tujuan dari hukum merupakan untuk mewujudkan keadilan, kemanfaatan, dan kepastian hukum. Pelindungan bagi para pihak (bank dan konsumen) dalam bank beku operasi dilindungi oleh LPS (lembaga penjamin simpanan) dari ketentuan Pasal 54 Undang-Undang Lembaga Penjamin Simpanan. Kewajiban pihak bank yang telah dijamin oleh lembaga penjamin simpanan yaitu:

- Tetap membayarkan gaji karyawan yang terutang

- Memberikan suatu pesangon pada karyawan

- Suatu biaya perkara untuk biaya lelang yang terutang, dan biaya operasional.

- Biaya penanganan yang dilakukan oleh lembaga penjamin simpanan dan atau pembayaran klaim penjaminan yang harus dibayarkan Lps.

- Pajak Terutang Membayar sebagian simpanan dari nasabah penyimpan yang tidak dibayarkan penjaminnya dan simpanan dari nasabah penyimpan yang tidak dijamin

- Hak lain Kreditor

- Hak Konsumen nasabah apabila bank mengalami bank beku operasi yang dilindungi oleh Lembaga Penjamin Simpanan: Lembaga penjamin simpanan (LPS) akan menjamin simpanan nasabah baik itu deposito, sertifikat tempat tinggal /tanah yang dijadikan jaminan pada bank tadi, yang layak bayar dan untuk simpanan yang tidak layak bayar atau dijamin pembayarannya melalui prosedur ketentuan bank pada beku operasi atau likuidasi (Zaeni, 2005).

Dengan demikian inti menurut permasalahan baik pihak bank juga pihak konsumen nasabah telah di jamin dan diawasi oleh LPS (Lembaga penjamin simpanan). Sebagaimana Lembaga Penjamin Simpanan diatur pada Undang-Undang No. 24 Tahun 2004.

\section{Upaya Penyelesaian Jika Bank dinyatakan sebagai Bank Beku Operasi bagi Nasabah dalam Jual Beli Perumahan Secara Kredit}

Sistem Perbankan di Indonesia adalah seluruh yang terlibat dalam bank, termasuk kelembagaan, aktivitas usaha, beserta cara suatu proses pada mencapai kegiatan usaha secara kesepakatan juga syariah yang dimaksud pada Undang- Undang tentang perbankan dan Undang-Undang tentang perbankan syariah. Menurut penjelasan tersebut hukum perbankan adalah aturan positif yang mengontrol seluruh entitas yang melekat dalam bank, menyangkut kelembagaan, aktivitas bisnis, dan cara proses pelaksanaan aktivitas usahanya (Usuwatun, 2017). Dalam perjalanan bank umum menjalankan tugasnya menjadi pemberi kredit bank mengalami bank beku operasi menyebabkan nasabah dirugikan menjadi penyimpan dana dan penyimpan kredit menjaminkan sertifikat sebagai agunan.

Bank beku operasi yaitu bank dibekukan oleh Bank Indonesia dan selanjutnya diserahkan dalam BPPN (Badan Penyehatan Perbankan Nasional) untuk tujuan menyelesaikan suatu tanggung jawab Bank melalui pertanggungan pemerintah, menyelesaikan suatu hak-hak, bersama dengan upaya pemulihan uang negara. Penyelesaian terhadap bank dalam beku operasi dilakukan menggunakan penanganan permasalahan pada bank tadi meliputi:

- Pengurusan perkara bank utamanya mengaplikasikan asal daya bank itu sendiri melalui taktik usaha tanpa mempergunakan aturan suatu negara.

- Jika upaya pengurusan ini tidak dapat menangani permasalahan yang ada, pengurusan penanganan permasalahan bank dilakukannya lewat dukungan Bank Indonesia untuk penanganan masalah likuiditas dan LPS (Lembaga Penjamin Simpanan) untuk penanganan masalah resiko keuangan.

- Dalam keadaan kritis finansial jika terjadi permasalahan pada sektor perbankan mampu menciptakan perkembangan ekonomi nasional dibahayakan, didasarkan pada rekomendasi Presiden KSSK (Komite Stabilitas sistem keuangan) bisa memutuskan diselenggarakannya acara restrukturisasi perbaikan oleh LPS dengan program LPS penanganan masalah atas bank.

Dalam hal ini upaya penyelesaian bank pada beku operasi yaitu nasabah bisa dengan cara pemberesan kekayaan bank yang bermasalah bisa diwujudkan upaya kepailitan. Sebagian teori bank bisa diajukan pailit dengan dilihat pada kewenangan yang pernah disampaikan Undang-Undang Kepailitan, atau penyelesaian bank yang gagal atau bank beku operasi diwujudkan dalam Badan 
Penyehatan Perbankan Nasional (BPPN). Setelah adanya Undang-Undang Lembaga Penjamin Simpanan (LPS) penyelesaian bank gagal yang dampaknya ke sistematik dilakukan oleh LPS mengikutsertakan pemegang saham (Zulkarnia, 2002).

\section{SIMPULAN DAN SARAN \\ 1. Simpulan}

Berdasarkan hasil dan pembahasan yang telah diuraikan di atas, ada beberapa simpulan yang dapat dibuat, yaitu: pertama, hak dan kewajiban para pihak dalam jual beli perumahan secara kredit pada bank yang dinyatakan beku operasi dilindungi oleh LPS (lembaga penjamin simpanan). Hak dari konsumen nasabah jika bank mengalami bank beku operasi yaitu mendapatkan perlindungan dari LPS yang akan menjamin simpanan nasabah baik itu deposito, sertifikat tanah yang menjadi jaminan pada bank, yang pantas membayar dan untuk simpanan tidak pantas membayar atau dijamin pembayarannya dalam mekanisme ketentuan bank dalam beku operasi. Sedangkan kewajiban dari pihak bank kepada nasabah yaitu salah satunya dengan membayar setengah simpanan daripada nasabah. Penyimpan yang tidak bisa dibayarkan oleh penjaminnya dan simpanan daripada nasabah, penyimpanan yang tidak terjamin, biaya penyelesaian yang dilakukan oleh lembaga penjamin simpanan dan atau pembayaran klaim penjaminan wajib dibayarkan LPS. Kedua, Upaya penyelesaian apabila bank dinyatakan sebagai bank beku operasi, nasabah pada jual beli perumahan secara kredit melakukan pemberesan harta bank yang bermasalah dengan mengajukan kepailitan. Bank bisa dibuat permohonan pailit dengan dilihat pada otoritas yang sudah diberikan Undang-Undang Kepailitan. penyelesaian bank yang gagal atau bank beku operasi sekarang ditempuh melalui Lembaga Penjamin Simpanan (LPS) menggunakan mengikutsertakan para pemegang saham.

\section{Saran}

Selain itu, ada juga beberapa saran yang perlu disampaikan kepada beberapa ihak, yaitu: pertama, supaya nasabah mengerti dan paham hak dan kewajiban para pihak bank dan nasabah jika bank mengalami bank beku operasi. Sebelum terjadinya bank yang dipilih mengalami beku operasi, seyogianya nasabah memilih lebih teliti bank mana yang akan dipilih buat menjaminkan sertifikat perumahannya. Jika sudah terjadi bank beku operasi, diharapkan bank beku operasi dibantu LPS mengembalikan dana nasabah dengan cepat dan tepat. Kedua, upaya penyelesaian bank yang mengalami beku operasi yang dilakukan upaya pailit dengan cara membereskan harta bank tersebut, diharapkan hasil dari membereskan harta bank tersebut dapat mengembalikan harta atau agunan milik nasabah yang dijaminkan berupa sertifikat, uang dan sebagainya di bank tersebut.

\section{DAFTAR PUSTAKA}

Hermansyah. (2008). Hukum Perbankan Nasional Indonesia. Jakarta: Kencana.

Kusumohamidjojo. (1998). Dasar-dasar Merancang Kontrak. Jakarta: Gramedia Widiasarana.

Oktafiani, L., \& Idris, R. (2015). Pelaksanaan Pemberian Kredit dengan Jaminan Hak Tanggungan pada Debitur PT. Bank DKI Jakarta Pusat. Lex Jurnalica, 12(2).

Prawira, M. R., \& Purwanto, I. W. N. (2020). Pembatalan Perjanjian Jual Beli secara Sepihak oleh Konsumen di PT. Restu Property. Jurnal Kertha Semaya, 8(12), 1875-1885.

Subekti, R. (1995). Aneka Perjanjian (10th ed.). Bandung: Citra Aditya Bakti.

Sutianingsih. (2010). Keputusan Konsumen dalam Membeli Perumahan. Riset Manajemen Dan Akuntansi, 1(2).

Thomas, S., Chalik, H., Made, S., Yunianti, A. T., \& Marala, D. T. (1999). Dasar-dasar Perkreditan. Jakarta: Gramedia Pustaka Utama.

Thomas, S., Marala, D. T., Azhar, A., Thomas, A. J., Yuniati, A. T., \& Chalik, H. (2007). Kelembagaan Perbankan. Jakarta: Gramedia Pustaka Utama.

Usuwatun, H. (2017). Hukum Perbankan. Malang: Setara Press.

Zaeni, A. (2005). Hukum Bisnis, Prinsip dan Pelaksanaannya di indonesia. Jakarta: Raja Grafindo Persada. Zulkarnia, S. (2002). Perlindungan Dana Nasabah Bank. Jakarta: LPS. 